\title{
The Implementation of Well-Known Trademarks Doctrine in Indonesian Commercial and Supreme Court
}

\author{
Sujana Donandi $\mathbf{S}^{1}$, Pandu Adi Cakranegara ${ }^{2}$ \\ ${ }^{1}$ Law Study Programme, Faculty of Humanities, President University, Indonesia, \\ E-mail:sujana@president.ac.id \\ ${ }^{2}$ Accounting Study Programme, Faculty of Business, President University, Indonesia, \\ E-mail: pandu.cakranegara@president.ac.id
}

Submitted: October 10, 2020; Reviewed: November 20, 2020; Accepted: December 12, 2020

\begin{tabular}{|c|c|}
\hline Article Info & Abstract \\
\hline $\begin{array}{l}\text { Keywords: } \\
\text { Implementation, Well-Known } \\
\text { Trademarks, Commercial and } \\
\text { Supreme Court } \\
\text { DOI: } \\
\text { 10.25041/fiatjustisia.v15no2.2016 }\end{array}$ & $\begin{array}{l}\text { The implementation of well-known trademark in } \\
\text { indonesia is still unsatisfying especially for foreign } \\
\text { trademarks since many foreign trademarks that } \\
\text { claimed themselves as well-known trademarks were } \\
\text { not admitted for the trademarks were not yet } \\
\text { registered or based on judges assessment, not } \\
\text { fulfilling the criteria. This research aim is to analyse } \\
\text { the implementation of well-known trademarks } \\
\text { doctrine in Indonesian commercial and supreme } \\
\text { court. The method used is normative-juridical with } \\
\text { statute and case study approach. The result shows } \\
\text { that the commercial and supreme court have used } \\
\text { the criteria of well-known trademarks as stipulated } \\
\text { in Law no. } 20 \text { Year } 2016 \text { and Permenkumham no. } 67 \\
\text { Year } 2016 \text { as well as WIPO Joint Recommendation } \\
\text { in identifying a well-known trademark. However, the } \\
\text { implementation is inconsistent. it is inconsistent } \\
\text { because in one case (STARCO case), court prior to } \\
\text { the first to file principle while in other case } \\
\text { (Alexander Mcqueen case), court admit the } \\
\text { trademark as a well-known trademark though it is } \\
\text { not registeredyet. The second case is coherencewith } \\
\text { the well-known trademark doctrine which the idea to } \\
\text { protect a high reputed trademark even it is not } \\
\text { registered. Secondly, the emptiness of the detailed } \\
\text { criteria has made the judgement on well-known } \\
\text { trademarks becomes widely opened for } \\
\text { interpretation. Thus, the next convention and } \\
\text { regulation must set aside the first to file principle } \\
\text { and prior to the criteria only in identifying a well- } \\
\text { known trademark. Moreover, the criteria of }\end{array}$ \\
\hline
\end{tabular}


minimum number of registration or application should be revised by requiring the trademark to be registered or applied in at least 6 out of 10 countries with the biggest population in the world so that it is proven that the trademark is exist among the most world population. In addition, the standard level of legal enforcement must entail minimum two verdicts so that the enforcement has obtained a reconfirmation.

\section{A. Introduction}

Trademark is a designation which is used for individualization of goods of legal entities or self-employed entrepreneurs. ${ }^{1}$ A trademark functions to identify the source of a product, serving as an indicia of source. ${ }^{2}$ Firms use trademarks to signal to consumers that the product is of a certain quality. ${ }^{3}$ Trademark is one of the important aspect in business activity. A well reputed trademark will bring a lot of benefits for the trademark holder. Large firms tend to derive positive significant benefit from trademarks and advertising intensities. ${ }^{4}$ Unlike a patent or copyright that will eventually expire, a trademark can be renewed indefinitely as long as the owner continues to trade. This permanence permits a firm to build a brand image using successive waves of advertising. Such a brand can act as a barrier to entry for new firms that have no established reputation. It can also permit the brand holder to enter new fields of enterprise using the reputation established in their existing product area. ${ }^{5}$ Considering all the benefit and long terms potential using, protecting a trademark by the holder becomes very essential to prevent other party to gain profit using the trademark unlawfully.

The legal issues related to the trademark are very diverse. One of them is related to the using of a trademark without permission. The unauthorized use of a trademark occurs when a company uses part or all of another company's brand name, logo, slogan, package design, or any other brand element to

\footnotetext{
${ }^{1}$ Irina Suslina, Polina Mineeva, "Use of Digital Technologies for Optimizing The Handling of Trademarkss Application”, Procedia Computer Science 169, (2020): 435-439, 436, DOI: 10.1016/j.procs.2020.02.242.

${ }^{2}$ Doug Bania, "Can Trademark Infringement Be a Victimless Crime? The Stone v. Omnia Case", International Journal of Law and Public Administration 1, no. 2 (2018): 41-46, 45, DOI: 10.11114/ijlpa.v1i2.3879.

3 Miresi Cela, "The Importance of Trademarkss And A Review of Empirical Studies", European Journal of Sustainable Development 4, no. 3 (2015): 125-134, 129, DOI: 10.14207/ejsd.2015.v4n3p125.

${ }^{4}$ Ilayda Nemlioglu and Sushanta K. Mallick, "Do Innovation-Intensive Firms Mitigate Their Valuation Uncertainty During Bad Times?", Journal of Economic Behaviour and Organization 177 (2020): 913-940, 914, DOI: 10.1016/j.jebo.2020.06.004.

${ }^{5}$ Christine Greenhalgh and Elizabeth Webster, "Have Trademarks Become Deceptive?", The WIPO Journal 6, no. 2 (2013): 1-8, 5.
} 
confuse people into buying the product. ${ }^{6}$ The other possible legal matter is passing off or claiming others trademark. It could be happened especially to a trademark with good reputation and has multitude customers.

In His research, Jeon found consumers' emotional attachment has a positive influence on customer commitment. Moreover, emotional attachment was positively and significantly affected by brand benefit including aesthetic and symbolic brand concepts. ${ }^{7}$ Brand can create the value for customers and result in more revenue for the company. ${ }^{8}$ Though not all trademarks are brand but brand is part of trademark so that we could found that there is relation between the concept of a trademark and consumer engagement. The more valuable a trademark for a customer the more known they are. According to Chaudhary, today, well-known trademarks enjoy special protection under the law because of their 'brand value'. Over the years, the law has changed so much that a trademark owner can oppose a deceptively similar trademark even at the stage of latter's registration. ${ }^{9}$ As result, it is possible that someone registers a particular trademark which actually has been famous in numerous countries, but not registered in his country.

The definition of a well-known trademark is not precisely descrribed in Indonesian Law Number 20 Year 2016 concerning Trademarks and Geographical Indication hereinafter called 'Trademark \& GI Law'. However, it is mentioned in some part of the law, as in Indonesian it is called 'Merek Terkenal'. Firstly, it is mentioned in Article 21 paragraph (1) b which governs that an application of a trademark will be rejected if the proposing trademark contains similarity in essence or in total with a well-known trademark owned by other parties for the similar goods and or services. In part ' $c$ ', it is stated that the well-known trademarks belong to the other parties should comply particular requirement. Further, the explanation of the law describes that the consideration of a mark to be entitled as a well-known trademark must notice the public knowledge towards the trademark, the reputation obtained by the trademark through a massive promotion, and investment in some countries followed by the evidence of the registration in such countries. In addition, the explanation of the law also regulates that if necessary, the commercial court

\footnotetext{
${ }^{6}$ Tahsan Rahman Khan, "Family Businesses That Produce Counterfeits: What is Stopping Them From Creating Their Own Brand?", Procedia Economics and Finance 4, (2012): $304-$ 311, 305, DOI: 10.1016/s2212-5671(12)00345-0.

7 Joo-Eon Jeon, "The Impact of Brand Concept on Brand Equity”, Asia Pacific Journal of Innovation and Entrepreneurship 11, no. 2 (2017): 233-245, 241, DOI: 10.1108/APJIE-082017-030.

8 Ebrahim Chirani, Mohammad Teleghani, and Nasim Esmailie Moghadam, "Brand Performanca and Brand Equity", Interdisciplinary Journal of Contemporary Research Business 3, no. 9 (2012): 1033-1036, 1035.

${ }^{9}$ Vivek Kumar Choudhary, "Protection of Well Known Trademarks and Weakening of Honest Concurrent User Defense", Journal of Intellectual Property Rights 15, no. 4 (2010): 300-310, 300 .
} 
could order an independent institution to conduct a survey to find a conclusion whether the trademark is well-known or not.

The governance of a well-known trademark in Trademark and GI Law can also be found in the explanation of Article 76 Paragraph (2) in referring to the term 'the owner of an unregistered trademark'. In the explanation, it is described that the one called as the owner of an unregistered trademark is including the owner of an unregistered trademark. Lastly, admission of a wellknown trademark in Trademark and GI Law is stipulated in the explanation of Article 83 Paragraph (2) which states that the giving of right to propose a lawsuit based on a fraud conducted by other party is aimed to provide legal protection for the owner of unregistered well-known trademark.

Based on the provisions and explanation in Trademark and GI Law, Authors infer that a well-known trademark is admitted in Indonesian legal system. To be recognized as a well-known trademark, a mark should fulfil some qualification including the public knowledge, massive promotion, investment, as well as evidence of registration in some country. By obtaining status as a well-known trademark, a mark will be protected by the Indonesian law, even though the mark is not registered yet in Indonesia.

A further governance on how to determine a well-known trademark in Indonesia is stipulated in the Regulation of The Ministry of Law and Human Rights Number 67 Year 2016 concerning the trademarks registration hereinafter called Permenkumham of Trademarks Registration. In article 18, it is ruled that to be recognized as a well-known trademark, a trademark must qualify several requirements namely: public knowledge which can be identify by considering the level of knowledge or recognition in the related business sector, volume of sales and profit gained by the using of the trademark, market share, the territorial range of the using of the trademark, duration of using, instensity and promotion, registration or application of registration in other countries, the level of success upon the trademark legal enforcement, especially regarding the admission of the trademark as a well-known trademark, and the trademark value gained by reputation or guarantee of the product quality.

The existence of a well-known trademark in Indonesia is a part of Indonesian effort in enforcing law of trademark. This enforcement is a part of Indonesian activity in international engagement. Indonesia have admitted Paris Convention through The Presidential Decree Number 24 Year 1979 and consequently the admission need to be implemented and to apply the commitment Indonesia should have its owned regulation on trademarks. Thus, Indonesia then made law on trademark which the latest one is Trademarks and GI Law.

Indonesia joins the Paris Convention which one of the substance is to protect a well-known trademark. Hence, it is important to see how the Paris Convention regulates the well-known trademark protection since the idea of 
the well-known trademark in member states is initiated by the Paris Convention. The well-known trademark protection is contained in Article 6bis below:

Article 6bis

Marks: Well-Known Marks

(1) The countries of the Union undertake, ex officio if their legislation so permits, or at the request of an interested party, to refuse or to cancel the registration, and to prohibit the use, of a trademark which constitutes a reproduction, an imitation, or a translation, liable to create confusion, of a mark considered by the competent authority of the country of registration or use to be well known in that country as being already the mark of a person entitled to the benefits of this Convention and used for identical or similar goods. These provisions shall also apply when the essential part of the mark constitutes a reproduction of any such wellknown mark or an imitation liable to create confusion therewith.

(2) A period of at least five years from the date of registration shall be allowed for requesting the cancellation of such a mark. The countries of the Union may provide for a period within which the prohibition of use must be requested.

(3) No time limit shall be fixed for requesting the cancellation or the prohibition of the use of marks registered or used in bad faith.

The stipulation in Article 6bis explicates a shared commitment to preserve a well-known trademark towards the similarity or even sameness by the other trademark. When applied correctly, the well-known marks doctrine promotes the same goal of free trade that registration fosters. Consumer recognition does not provide a separate basis for protection of a trademark but acts instead as a safety valve. Allowing entrepreneurs to take advantage of the recognition garnered by a foreign trademark in Member nations where it has not been registered or used would disincentivize entities from expanding abroad. ${ }^{10}$

Further, the international commitment in Protecting the Well-Known Trademark is consented in Article 16 (2) Trade Related Intellectual Property Rights (TRIPs) as stipulated below:

Article 6bis of the Paris Convention (1967) shall apply, mutatis mutandis, to services. In determining whether a trademark is wellknown, Members shall take account of the knowledge of the trademark in the relevant sector of the public, including knowledge in the Member concerned which has been obtained as a result of the promotion of the trademark.

\footnotetext{
${ }^{10}$ Leah Chan Grinvald, "The Tale of Two Theories of Well-Known Marks", Vanderbilt Journal of Entertainment and Technology Law 13, no. 1 (2010): 18-26, 19.
} 
Based on the provison, the following elements are required of a foreign mark owner to prevail in a well-known marks case: ${ }^{11}$

1. the foreign mark is a valid trademark;

2. the foreign mark has not been previously registered (or used) in the Member nation where a local entity seeks to register (or use) the mark;

3. such registration or use involves identical or similar goods for which the foreign trademark is registered or used in the foreign mark owner's home nation;

4. the foreign mark is well known in the Member nation; and

5. confusion is likely to arise from the local entity's registration or use.

In the development, to ease the understanding of those recognized as a well-known trademark, World Intellectual Property Organization (WIPO) as the international organization handling the intellectual properties matters globally have issued recommendation regarding the criteria of well-known trademarks. The points of well-known traits of WIPO are contained in the 'Joint Recommendation Concerning Provision on The Protection of WellKnown Marks' Part 1 Article 2 as follows:

(1) [Factors for Consideration]

(a) In determining whether a mark is a well-known mark, the competent authority shall take into account any circumstances from which it may be inferred that the mark is well known.

(b) In particular, the competent authority shall consider information submitted to it with respect to factors from which it may be inferred that the mark is, or is not, well known, including, but not limited to, information concerning the following:

1. the degree of knowledge or recognition of the mark in the relevant sector of the public;

2. the duration, extent and geographical area of any use of the mark;

3. the duration, extent and geographical area of any promotion of the mark, including advertising or publicity and the presentation, at fairs or exhibitions, of the goods and/or services to which the mark applies;

4. the duration and geographical area of any registrations, and/or any applications for registration, of the mark, to the extent that they reflect use or recognition of the mark;

5. the record of successful enforcement of rights in the mark, in particular, the extent to which the mark was recognized as well known by competent authorities;

6. the value associated with the mark.

${ }^{11}$ Leah Chan Grinvald, Loc.Cit. 
(c) The above factors, which are guidelines to assist the competent authority to determine whether the mark is a well-known mark, are not pre-conditions for reaching that determination. Rather, the determination in each case will depend upon the particular circumstances of that case. In some case all of the factors may be relevant. In other case some of the factors may be relevant. In still other cases none of the factors may be relevant, and the decision may be based on additional factors that are not listed in subparagraph (b), above. Such additional factors may be relevant, alone, or in combination with one or more of the factors listed in subparagraph (b), above.

(2) [Relevant Sector of the Public]

(a) Relevant sectors of the public shall include, but shall not necessarily be limited to:

(i) actual and/or potential consumers of the type of goods and/or services to which the mark applies;

(ii) persons involved in channels of distribution of the type of goods and/or services to which the mark applies;

(iii) business circles dealing with the type of goods and/or services to which the mark applies.

(b) Where a mark is determined to be well known in at least one relevant sector of the public in a Member State, the mark shall be considered by the Member State to be a well-known mark.

(c) Where a mark is determined to be known in at least one relevant sector of the public in a Member State, the mark may be considered by the Member State to be a well-known mark.

(d) A Member State may determine that a mark is a well-known mark, even if the mark is not well known or, if the Member States applies subparagraph (c), known, in any relevant sector of the public of the Member State.

(3) [Factors Which Shall Not Be Required]

(a) A Member State shall not require, as a condition for determining whether a mark is a well-known mark:

(i) that the mark has been used in, or that the mark has been registered or that an application for registration of the mark has been filed in or in respect of, the Member State;

(ii) that the mark is well known in, or that the mark has been registered or that an application for registration of the mark has been filed in or in respect of, any jurisdiction other than the Member State; or

(iii) that the mark is well known by the public at large in the Member State. 
(b) Notwithstanding subparagraph (a)(ii), a Member State may, for the purpose of applying paragraph $(2)(d)$, require that the mark be well known in one or more jurisdictions other than the Member State.

According to the provision of Article 6bis, 16 (2) TRIPs and WIPO Joint Recommendation, Authors can conclude that a well-known trademark is a joint-belief of the member country that a trademark with a high reputation should obtain legal protection though it is not registered because its reputation gives the trademark privilege to be recognized as a 'Well-known trademark'. A common beliefs which then followed by the member states then become a doctrine that must be enforced by the law. In Indonesia, the enforcement system has been legally formed through the Trademarks and GI Law which the contents are in majority coherence with the international convention.

Though Indonesia have formally governs the well-known trademark, however, the implementation is still irresolute. Two concrete cases are the case of 'Superman' and 'Pierre Cardin' trademarks. Superman is a very well-known character as well as trademark owns by DC Comics. Meanwhile, 'Pierre Cardin' is a very famous trademark from France. Superman was then registered in Indonesia by Indonesian entrepreneur from Surabaya while Pierre Cardin was registered by a business actor from Jakarta. DC Comics and Pierre Cardin from France were then submitted a lawsuit against the registration of their trademarks by the Indonesian entrepreneurs. A debatable issue during the court procedures was that the Indonesian business men won the case though the both trademarks have been proven exist long before the trademarks were registered in Indonesia and even the both trademarks are recognized overseas.

The both cases show a dynamic in legal protection of well-known trademarks in Indonesia. In both cases, the argumentation and evidence such as registration and marketing of their trademarks internationally have been proposed by DC Comics and Pierre Cardin from France. However, the DC Comics and Pierre Cardin lost the case. In Superman case, the DC Comics lawsuit was sentenced unacceptable (niet on vanklicht verklaard) by the commercial court because the court considered that the lawsuit is not clear. The commercial court decision then confirmed by the Supreme Court in cassation based on Verdict Number 1105 K/Pdt.Sus-HKI/2018. Thus, it is hard to see how the judges examine the issue of 'well-known trademark' in that case. Meanwhile, in Pierre Cardin case, based on verdict of Commercial Court number 15/Pdt.Sus-Merek/2015/Pn.Niaga.Jkt.Pst, it can be concluded that the Pierre Cardin lawsuit is rejected though the court admit there is a similarity in phonetics but since the products that produced by the Indonesian clearly mention 'Made in Indonesia' in their product then the judges considered there is no potential of misleading of the using of the trademark. Moreover, the judges also prior to the first to file principle and considered that the Pierre Cardin from France can not show the evidence as a well-known 
trademark before it was firstly registered in July 291977 by an Indonesian. The verdict was then also confirmed by the Supreme Court in cassation.

The Pierre Cardin case has shown that the board of the judges have their own consideration in identifying a well-known trademark, that it must be proven well-known prior to the first to file principle in Indonesian Law. It means that any party who firstly registers the trademarks in Indonesia will be entitled as the owner of the trademarks. And as in Superman case, though the trademark is well-known, it must be proven well-known before it was firstly registered in Indonesia. Otherwise, then it is not recognized well-known. It is, however, is contrary to the idea of well-known trademark doctrine as agreed internationally which is to protect a high reputed trademark even though the trademark is not registered in member states.

Situation mentioned above attracts the Authors attention to examine various cases on well-known trademark in Indonesian court (both commercial and supreme court), especially to see its correlation with the well-known trademark doctrine. The aim of this research is to explain and describe the implementation of the well-known trademark doctrine in Indonesian commercial and supreme court. The method in this research is normative juridical which is a legal research focused on the analysis towards the existing norms such as law and jurisprudence. The approach are statute and case study. The statute approach is done by involving the current regulation in analyzing the examined issue. Meanwhile, case study approach is used in order to find important facts regarding the problem identified in concrete and related cases. In application, this research run by analyzing the verdicts in Indonesian commercial and supreme court in order to find out how the courts considering a well-known trademark. After that, the data will be examined using the wellknown trademark doctrine to find the coherency between the verdicts and the doctrine.

\section{B. Discussion}

To be able to answer problem regarding the implementation of wellknown trademark doctrine in Indonesian commercial and supreme court, in advance, Authors will examine relevant cases to see how the judicial body in Indonesia implement the law related to the well-known trademarks. The analyzed cases in this research are cases related to the well-known trademarks. The subject relating whether the case has relation with the issue of a wellknown trademark or not is based on The Authors' tracking towards the court verdicts in which in those cases some involved party was claiming their trademark as a well-known trademark. Beside that, The Authors also have reviewed how the judges settling the cases were giving their consideration to the claim. By this, The Authors could analyze the judges judgement whether the claimed trademark is a well-known trademark or not. 
The analyzed cases are cases tried using the latest law namely Law Number 20 Year 2016 concerning on The Trademark and Geographical Indication. The law was legalized in November 25, 2016. Based on The Authors' searching, a lot of cases settled after November 2016 is pleaded based on the old law namely Law Number 15 Year 2001 concerning trademark because the disputes was initially started before the latest law was issued. Therefore, The Authors chose to analyze cases settled using the latest law only so that this research could give a factual and significant contribution to the development of law science particularly to the law of trademark recently and in the future as long as the existing law is still used and valid. The Authors found 5 cases settled using Law Number 20 Year 2016 in which in the verdict the judges gave judgement regarding the claim of well-known trademark status by the disputing parties. Based on the Supreme Court Directory, all the verdicts of the cases are now final and binding (inkracht). The 5 cases were settled by the court (commercial court and supreme court) between 2017 and 2020. Those cases are as explained below:

\section{SAMHWA Trademark Case (Judge Verdict number 06/Pdt. Sus- Merek/2018/PN.Niaga.Jkt.Pst)}

The SAMHWA case is a dispute between SAMHWA PAINTS IND.CO.LTD or hereinafter called Samhwa Paints, a legal entity established based on State of South Korea's Law against Henry Chandra Tjo or hereinafter called as Chandra Tjo, an entrepreneur from Indonesia. This case was also dragged The General Directorate of Intellectual Property or hereinafter called Dirjen HKI as the authorized institution handling the intellectual property registration as the Shared Defendant. This case was initiated by the objection of Samhwa Paints upon the registering 'SAMHWA' trademark proposed by Chandra Tjo in Dirjen HKI. Samhwa Paints claimed the registration by Chandra Tjo is a law infringement towards 'SAMHWA' trademark that Samhwa Paints claim belongs to them.

Samhwa Paints argued that their company that produce various kind of paint, protective metal, wood preservative, and natural resin under the 'SAMHWA' Trademark have been established since 1946, long before 'SAMHWA' trademark is used by Chandra Tjo. Samhwa Paints claimed that their 'SAMHWA' is a well-known trademark. The well-known of the trademark was claimed to be able to be tracked in search engine www.google.com that when we put keyword 'SAMHWA', there will be many references to the products with 'SAMHWA' trademark owned by the Samhwa Paints that at least consist of 141.000 search results, and all of the general searching was consistently referred to 'SAMHWA' trademark owns by Samhwa Paints. Moreover, Samhwa Paints also claimed that their 'SAMHWA' trademark is a well-known trademark for it has been registered in Korea, United States of America, China, Malaysia, and Vietnam. Therefore, 
Samhwa Paints requested the cancellation of Chandra Tjo's 'SAMHWA' trademark registration in Dirjen HKI.

Chandra Tjo rejected the claim and contended his side was the lawful holder of the 'SAMHWA' Trademark in Indonesia. This is based on the valid registration of Chandra Tjo's 'SAMHWA' trademark in Dirjen HKI. According to Chandra Tjo, based on the first to file system adopted by the trademark protection system in Indonesia, then it is obvious that the first party registering a trademark in which then the registration was granted will be considered as the legal owner of the trademark. Chandra Tjo also denied the claim of Samhwa Paints that mentioned themselves as a well-known trademark because since 2011 to 2018, Samhwa Paints never and seemed skeptical to do sales in Indonesia. Thus, for Chandra Tjo, 'SAMHWA' Paints could not claim themselves well-known worldwide.

The Commercial Court of Central Jakarta have made decision upon the case and the main content of the verdict was to reject the lawsuit of Samhwa Paints. In the other word, this case was won by Chandra Tjo and Chandra Tjo is the lawful holder of 'SAMHWA' trademark in Indonesia. In their consideration, the board of the judges sentenced that based on the provided proofs, The Judges were not able to determine 'SAMHWA' trademark by Samhwa Paints that registered in several countries is still actively gains protection or not. Therefore, the judges concluded that 'SAMHWA' by Samhwa Paints was not a well-known trademark and therefore the lawsuit is reasonable to be rejected.

\section{STARCO Case (Verdict number 04/Pdt.Sus-Merek/2018/PN Niaga.Jkt.Pst)}

The dispute involved STARCO EUROPE A/S hereinafter called Starco Europe, a company from Denmark as the plaintiff versus PT. Solihin Jaya Industri hereinafter called Solihin Jaya, an enterprise from Surabaya as The Defendant and also Dirjen HKI as the Shared Defendant. The background of the case was that Starco Europe found that there was a 'STACO' trademark registered by Solihin Jaya in Dirjen HKI. Starco Europe considered the trademark has similarity with their 'STARCO' trademark and considered there was a violation of trademark law committed by the Solihin Jaya. Hence, Starco Europe filed a cancellation upon the 'STACO' trademark to the Commercial Court.

In their lawsuit Starco Europe postulated that their 'STARCO' trademark was a well-known mark. Starco Europe explained that they have registered the trademark in the World Intellectual Property Organization (WIPO) and several other countries namely Australia, Canada, New Zealand, Chile, Argentine, South Africa, and China. By the registration of 'STARCO' in the mentioned countries, Starco Europe considered that their 'STARCO' trademark deserved to be entitled as a well-known trademark. 
Solihin Jaya objected the argumentation that 'STARCO' trademark claimed by Starco Europe was a well-known trademark. According to Solihin Jaya. 'STARCO' trademark did not fulfil the criteria as stipulated in the explanation of Law number 20 Year 2016 regarding Trademark and Geographical Indication, which firmly states the criteria of a well-known trademark, including noticing 'general knowledge of Indonesian society' regarding the trademark in the related business sector in Indonesia and considering the reputation the trademark gained by the big and intensive promotion in Indonesia.

Solihin Jaya added that the existence of the public knowledge is very essential and is an absolute requirement (condition sine quanon), which means that to be recognized as a well-known trademark must be recognized well by the society in Indonesia. In Solihin Jaya's opinion, the trademark claimed by the Starco Europe was not fulfilling the criteria of the 'public knowledge' in Indonesia in the related business sector because in fact, a lot of Indonesian people do not recognized 'STARCO' trademark claimed by Starco Europe. Solihin Jaya also claimed that there was no intensive promotion by the Starco Europe so that the trademark is not known well by Indonesian people for it had no high reputation and had no mythical context with Indonesian citizens widely.

The court decided the case and the core point of the verdict was that the judges denied the lawsuit of Starco Europe. In their consideration, judges sentenced that after conducting a careful examination the judges found that the Starco Europe's registration in the other countries was preceded by Solihin Jaya so that Starco Europe's trademark was not deserved to be recognized as a well-known trademark. Because of the trademark of Starco Europe was not considered as a well-known trademark, so that the Starco Europe's lawsuit should be rejected by the court.

\section{Nippon Case (Reconsideration verdict number 114 PK/Pdt. Sus- HKI/2019}

Nippon trademark case is a dispute between Nippon Wiper Blade CO., LTD, or hereinafter called Nippon Co, a company from Japan against Romy Sianaryo, an entrepreneur from Jakarta. The case was started when Nippon Co noticed that 'NWB' trademark was registered on behalf of Romy Sianaryo in Dirjen HKI in 2013. Nippon co have been established since 1965 and working in the production of glass cleaner for vehicles including the parts for the window and vehicles glass where they already registered 'NWB' since 1988 and keep on producing until now worldwide so that they considered that there has been an infringement by Romy Sianaryo's trademark.

Nippon Co believed that there has been a violation upon ' $N W B$ ' trademark that they considered as a well-known trademark. 'NWB' trademark has been registered by Nippon Co in numerous countries such as Taiwan, 
Malaysia, Thailand, Japan, Switzerland, Greece, Philippine, Singapore, Hongkong, Pakistan, Srilanka, United States Canada, Brazil, England, Spain, Netherland, Germany, Italy, Sweden, South Korea, and Mexico. The promotion of the trademark has also been done online in www.nwb.co.jp. Nippon Co also appointed that they have made an intensive investment and promotion of their product by the existence of officials distributors of their trademark products in countries such as United States, Malaysia, and Korea. Based on the mentioned reason Nippon Co accused that Romy Sianaryo has been committed to a passing off upon their 'NWB' trademark. Nippon Co claimed that Romy Sianaryo's registration has been done with a bad faith.

Nippon Co's argumentation was denied by Romy Sianaryo. For Romy Sianaryo, it was Nippon Co who was committed to the passing off instead. Thus, Romy Sianaryo countered the lawsuit by filling a counter lawsuit against Nippon Co and claimed that it was Nippon Co as the one with a bad faith for they were planning to register a trademark in Indonesia that previously has been registered by Romy Sianaryo. Therefore, Romy Sianaryo believed that his party was the one who was suffering from financial loss.

The case has been tried before the Commercial Court and has been deciced, and then continued to the Supreme Court. The Supreme Court in their decision both in cassation and reconsideration level agreed that the 'NWB' trademark registered by Romy Sianaryo has proven containing in total or at least the basic, similarity with the 'NWB' trademark by Nippon Co. On the other word, the NWB registration made by Romy Sianaryo was done in a bad faith.

\section{Mcqueen Case (Commercial Court Verdict number 04/Pdt. Sus- Merek/201/PN.Niaga.Jkt.Pst.}

Mcqueen case was a dispute between Autumnpaper Limited, a company from England and Wales againsted Richard Tionardi, an entrepreneur from Medan. In the case, Autumnpaper Limited also pulled Dirjen HKI as the Shared Defendant. The case was started when Autumnpaper Limited found that in The General List of Trademark in Dirjen HKI, a trademark 'MC QUEEN' was registered on behalf of Richard Tionardi. According to Autumnpaper Limited, the 'MC QUEEN' registration by Richard Tionardi was violating their 'Alexander Mcqueen' trademark.

In one of their legal argumentation, Autumnpaper Limited argued that their 'Alexander Mcqueen' is a well-known trademark. Autumnpaper Limited stated that the development and deployment of the using of 'Alexander Mcqueen' was high and the trademark is exist in various countries marked with the opening of stores selling the product with 'Alexander Mcqueen' trademark in London, Milan, New York, Los Angeles, and Las Vegas since 2000 followed by the opening in China in 2011, as well as the opening of the 
online store in United States and England. It also has been registered in various countries,

In the verdict upon the case, the judges won Autumnpaper Limited and considered that the registration of 'MC QUEEN' trademark was done in a bad faith. In one part of the judges consideration, it is stated that the one called as a well-known trademark is a trademark that has been widely known by the public based on the reputation gained by the sustainable production by the owner followed by the trademark registration in various countries. Therefore, in the verdict, the judges considered the 'Alexander Mcquuen' trademark registration in Saudi Arabia, China, Malaysia, United States, South Africa, Mexico, Canada, European Union, and Australia as well as its distribution and promotional effort as the basis to sentence that 'Alexander Mcqueen' is a wellknown trademark. Hence, The Judges then ordered Dirjen HKI to register the cancellation and write off 'MC QUEEN' trademark from The General List of Trademark.

\section{GS Case (Supreme Court Verdict number 68 K/Pdt. Sus-HKI/2020)}

GS trademark case was a dispute between GS Yuasa Corporation hereinafter called Yuasa Corp, a company of accumulator from Japan and PT. Golden Surya Jaya hereinafter called Golden Surya, a company from Depok, Indonesia. The lawsuit of Yuasa Corp in this case also pulled Dirjen HKI as the Shared Defendant. The dispute was initially occurred by the registered 'GSJ' trademark by Golden Surya. According to Yuasa Corp, the 'GSJ' trademark has similarity with their 'GS' trademark.

In their lawsuit, Yuasa Corp argued that their trademark was a wellknown trademark. Hence, Yuasa Corp considered that the existence of 'GSJ' by Golden Surya could be considered has been done in a bad faith. The basis of Yuasa Corp argumentation was that their trademark has been recognized as a well-known trademark by the Supreme Court in several court verdicts in other cases as follows:

a. Verdict No. 019 PK/Pdt.Sus/2007 against GS GOLDSHINE trademark by Lucy Darmawati Waluyo;

b. Verdict No. 020 PK/Pdt.Sus/2007 against GS GOLDSTAR trademark by PT. Parahyangan Putra Pribumi;

c. Verdict No. 130 PK/Pdt.Sus-HKI/2014 against GISI trademark by PT. Gramitrama Battery Indonesia; dan

d. Verdict No. 55 K/Pdt.Sus.HKI/2015 against GS GARUDA SAKTI trademark by Yudhi Tanto.

Yuasa Corp also stated that their party have done a wide promotion of the 'GS' trademark in many countries worldwide, including Indonesia. Because of the long term using, promotion, and wide advertisement done consistently in years, Yuasa Corp considered their mark as a trademark that has been known for a long period of time. The recognition of their trademark 
was as a trademark of high quality product, therefor it deserved to be entitled as a well-known trademark. Yuasa Corp has also elaborated their income and other financial data to support the position of their trademark as a well-known trademark. One of them that The Authors quote was the number of the selling of GS accumulator/battery in Indonesia including the export number to the other country in 2022 which reached more than 500 billion rupiahs.

Yuasa Corp added that 'GS' trademark is also independently and consistently listed on the top number 1 TOP BRAND awards for accumulator/battery category since 2012 to 2018 - based on the survey made by Frontier Consulting Group. Yuasa Corp also claimed that they obtained the trademark registration in more than 130 countries including Indonesia and in some country the registration is not including the battery and related product but also in several other class. The most initial registration of GS trademark and still applied until now is in the country of origin of Yuasa Corp, Japan.

On the case, the judges admitted that the trademark of Yuasa Corp was firstly used in 1908 and registered in Japan with number: 00686702 dated May 5, 1913 for class of goods 9. Meanwhile in Indonesia, the first registration was in 1958 with registration number 63999 that has been extended regularly with the latest one was on January 182005 number IDM000027599 and gained protection until 2004. The judges considered that GS trademark by Yuasa Corp as a well-known trademark so that the trademark of Golden Surya that was registered in January 31, 2018 and gained protection until July 12, 2023 was considered made in a bad faith.

In addition, The judges was also using the verdict of the previous cases of Yuasa Corp related to their GS trademark as one of the consideration. In the previous cases faced by the Yuasa Corp, the settling courts were also admitted the 'GS' trademark by the Yuasa Corp as a well-known trademark. Therefore, the judges settling dispute between Yuasa Corp and Golden Surya chose to entitled the status of GS by Yuasa Corp as a well-known trademark too. As the consequence, the court ordered Dirjen HKI to cancel the trademark registration of Golden Surya by crossing out the trademark from The General List of Trademark and announcing it at the trademark official news as stipulated in the law of trademark and Geographical Indication. Against the verdict by the commercial court, Golden Surya followed a cassation procedure, however, the lawsuit was also rejected by The Supreme Court.

\section{Analysis:}

The explained cases above shows that in some case, commercial and supreme court have implemented the criteria of a well-known trademark as stipulated in Trademark law, Permenkumham of Trademark Registration, and WIPO Joint Recommedation. For example, the judges considered the number of the registration of the trademark in another country (Samhwa and Mcqueen Case). This is coherence with the provision of Article 18 Paragraph $3 \mathrm{~g}$ 
Permenkumham of Trademark Registration Law and Part 1 Article 2 paragraph 1.b. point 4. WIPO Joint Recommendation. There is also verdict that used the level of legal enforcement of the trademark as the basis of determining a trademark is a well-known trademark. It is provided in GS trademark case. It is coherence with the provision 18 Paragraph $3 \mathrm{~h}$ Permenkumham of Trademark Registration Law and Part 1 Article 2 paragrapgh $1 \mathrm{~b}$ point 5 WIPO Joint Recommendation. Meanwhile, regarding the reputation aspects, some verdict also used it as a consideration in identifying a well-known trademark (Mcqueen case). It is coherence with Article 18 Paragraph 3 i Permenkumham of Trademark Registration Law and Part 1 Article 2 paragraf $1 \mathrm{~b}$ point 6 WIPO Joint Recommendation.

It is also found that in some case, the judges are too bound to the first to file principle, so that even though a trademark is already registered and wellknown in another country, as long as it is not registered yet in Indonesia, then it is not considered as a well known trademark. It can be viewed in case of STARCO. In the case, it is shown that even though The STARCO by Starco Europe was established earlier, however, for STARCO trademark was firstly registered by Solihin Jaya in Indonesia, then the court entitled Solihin Jaya as the authorized owner of the trademark even though the similarity is obviously appeared. However, in other case, the judges admitted the foreign trademark as a well-known trademark though it is not yet registered in Indonesia. It shown in the resume of 'Mcqueen' case that even though the 'Alexander Mcqueen' trademark was not registered in Indonesia, its registration in other countries became the basis of the judges to state that the 'Alexander Mcqueen' trademark by Autumnpaper Limited is well-known and therefore the later registration by Richard Tionardo was sentenced made in bad faith.

Moreover, The cases show that the implementation of the criteria of a well-known trademark as the applicative enforcement of the idea to protect a trademark with a certain level of reputation is still unclear and open for interpretation. The unclear provision in Indonesian rules regarding the standard of well-known trademark is understandable since the international regulation itself still regulates the matters too generally. Irawan and Bustani said that the recent trademark law only explain the criteria of well-known trademarks, so that the future law must explain it in more detail. ${ }^{12}$ The detail of standard is important as Mostert said that The standard triggering the protection of well-known trademarks is "risk of confusion" with a later sign, but only when the latter sign is associated with products identical or similar to that of the well-known trademark. Moreover, the Paris Convention itself

\footnotetext{
${ }^{12}$ Irawan and Bustani, “Analisis Pembatalan Merek Superman yang Memiliki Persamaan Pada Keseluruhnya Menurut UU Nomor 20 Tahun 2016 (Studi Putusan Nomor 1105K/PDT.SUSHKI/2018)", Jurnal Hukum Adigama 3, no. 1 (2020): 841-865, 858, DOI: 10.24912/adigama.v3i1.8929.
} 
indicates no specific evaluation standards for determining which trademarks should be considered well-known. ${ }^{13}$ Even though the criteria have been then tried to be elaborated by The WIPO Joint Recommendation, still, the provision can not provide a measured and assessable minimum requirement.

One of the example is about the criteria of 'the level of public knowledge and recognition' in the related business sector to determine a wellknown trademark. This provision tries to sentence that to be considered as a well-known trademark, then a trademark must be well recognized by the particular society. However, this provision does not give a further limitation on how the minimum requirement or how high the level of the public knowledge and recognition toward the trademark is to be considered as a wellknown trademark. In law 20 Year 2016, it is also mentioned that if needed, the court could ask a particular institution to make the research in identifying a well-known trademark. This provision in one side, tries to give a chance for a more detail investigation in identifying a well-known mark. Nevertheless, still there is no further and more specific criteria in such an identification so that relying the assessment to a particular body would still open for different interpretation by the both parties since there is no quantitative limitation. The opposite party would possibly mind and reject the decision of the researching body based on the emptiness of a detail criteria.

The other issue is about the limitation of the 'public society' as stipulated in Permenkumham number 67 Year 2016. In article 18 it is stated that the 'public society' is referred to the consumed society or society in general which has a good relation whether at the level of production, promotion, distribution, or sales to the goods and or services protected under the determined well-known trademark. However, there is no accurate limitation on the scope of the stipulated 'public society'. In a territorial context, there could be a trademark which is well-known in a particular region but not quiet famous at the other places. The meaning 'region' or area still need to be interpreted further to find the common understanding in analyzing how big the region or territory of the 'public society' is to confirm that the trademark has been known widely enough.

In the sense of minimum number of registration or application, there has still no specific limitation as well. For instance, in the Nippon Case, the judges considered that the registration of 'NWB' by Nippon Co in at least 22 countries as the basis to identify 'NWB' trademark by Nippon Co as a wellknown trademark. Meanwhile, the court in 'Mcqueen' case admitted the 'Alexander Mcqueen' by Autumnpaper Limited as a well-known trademark

\footnotetext{
${ }^{13}$ P. Stylianos Malliaris, "Protecting Famous Trademarks: Comparative Analysis of US and EU Diverging Approaches- The Battle Between Legislatures and The Judiciary Who Is The Ultimate Judge?", The Chicago-Kent Journal of Intellectual Property 9, no. 1 (2010): 45-59, 49.
} 
just because the trademark has been registered in 9 countries. Moreover, in SAMHWA case, the judges was unable to identify 'SAMHWA' by Samhwa Paints as a well-known mark because the judges could not verify the validation of the trademark registration in 5 countries as claimed by the Samhwa Paints. This situation in one side, has arising an ambiguity that what if the registration were confirmed, would the 'SAMHWA' by Samhwa Paints would be admitted as a well-known trademark for its registration in 5 countries? Then, what if a trademark only registered in two or even just one other country? Would it also be fulfilling the requirement of a well-known trademark? Such a kind of issue is still not governed clearly and all the consideration is depend on the judges. This kind of rule for the fairness reason, should be stipulated more precisely and scalable.

The standard of minimum number of registration in various country absolutely need a further provision. Beside the fairness issue, this condition also brings the matter of legal certainty. If we take a look at back to the wellknown trademarks doctrine as governed in Article 6bis Paris Convention, then the authorized country was the one who is competent to identify it. However, the implementing country should have a clear standard and minimum precise number of registration to determine a well-known trademark.

The problem of the lack of the specific requirement also exist in the criteria regarding the reach and promotion of the trademark. Just like the problem of the range of the reached territory, until now, there is still no clear provision regarding the limitation and promotion of a trademark to be considered a well-known trademark. Based on Indonesian law, the only possible way as been mentioned previously, the court could asked a certain institution to conduct a survey. However, even though the institution stated the trademark is a well-known trademark, still the decision would be opened for interpretation and debate, especially about the validation of method, data, and standard. Regarding the data in consumers survey, an empirical research made by by Bird and Steckel found that the limitation of the size of the defendant-submitted survey dataset is also a limitation. Defendants frequently limit themselves to critiquing the plaintiff's survey methodology and results. ${ }^{14}$

Moreover, the current system would impose the court to be the only one that can provide such proof. Such approach is not match with the nature of private law that the charged should be undertaken by the disputing party since the court actually has no interest but to decide the rightful party. Thus, the providing should be freely in the responsibility of the disputing party only. Thus. specific requirement is needed so that both parties would have equal and same basis in elaborating each claim and or objection. Furthermore, an exact

\footnotetext{
${ }^{14}$ Robert C. Bird and Joel H. Steckel, "The Role of Consumer Surveys in Trademark Infringement: Empirical Evidence from the Federal Courts", J. BUS. L. 14, no. 4 (2012): 1013 $1053,1031$.
} 
method and minimum requirement of the conduction of the survey must be established to create a standard and common method and requirement to be used by the disputing party to support their claim.

Above all, there are facts that in several cases the judges have set aside the reality that the similarity is exist and that the earlier using is obvious. Bairagi mentions that a mark shall not be registered as a trademark if it is of such nature as to deceive the public or cause confusion. It can be seen that 'similarity and identical nature of the trademark' and 'likelihood of deception and confusion' are the grounds for refusal to register them either as an absolute ground or a relative ground for refusal of registration, depending on the facts and circumstances of each case. ${ }^{15}$ Thus, there should be no doubt to identify the real owner of the trademark if there has been a prove that one trademark has been firstly recognized before the later one made its registration. The only main problem to solve is for the trademark office to do enough effort to make sure that the similar trademark has never been exist before a grant of a particular proposed trademark is approved.

Alfred Yuan States that a defendant becomes liable when its use of a mark creates "a likelihood of confusion" about whether the plaintiff is affiliated or associated with the defendant, or whether the plaintiff originated, sponsored, or approved of the defendant's goods. It matters not whether the defendant created confusion intentionally or accidentally. ${ }^{16}$ This opinion proposes judges to be realistic and enforce the law based on the reality and the living fairness in society. Since the both trademark found the same, no matter it is with a bad intention or not, the determinantion of the real owner could be specified.

Meanwhile, the inconsistency of the judges verdict as explained previously between STARCO and Alexander McQueen case has arised the problem of the certainty of law. The judges and current law supposed to be able to bring certainty in legal enforcement. As Luo states that the existing regulation as mentioned supposed to be able to be enforced consistently in order to provide justice for the society. Owners of well-known marks are afforded a unique institutional structure to enforce their exclusive rights through administrative agencies or courts. ${ }^{17}$ Recently, whether the earlier existence in another country would be used to identify a trademark is lawfully admitted and considered as a well-known trademark or not will be depend on the handling judges. Ideally, the law should be coherence so it can be

\footnotetext{
${ }^{15}$ Ashutosh Bairagi, "Trademark and the Problem of Its Infringement in The Case of Deceptive Similarity", in International Journal of Scientific Research 5, no. 3, (2016): 315-316, 316.

${ }^{16}$ Alfred C. Yen, "Intent and Trademarks Infringement", Arizona Law Review 57, no. 3 (2015): 715-745, 743.

${ }^{17}$ Jing 'Brad' Luo dan Subha Ghosh, "Protection and Enforcement of Well-Known Mark Rights in China: History, Theory, and Future", Northwestern Journal of Technology and Intellectual Property 7, no. 2 (2009): 119-161, 120, DOI: 10.2139/ssrn.1326398.
} 
implemented in the territories that admit the same law. In the matter of Intellectual Property sector like trademarks, the function of law is to give protection for the owner of intellectual property right from abuse of right like counterfeiting, fraud, unhealthy competition, etc. ${ }^{18}$ Thus, the consistency and coherency in legal practice must be established in order to give a maximum protection.

In The Authors opinion, based on the philosophical idea of wellknown protection doctrine as then agreed in Paris Convention, the recognition upon the well-known trademarks is to protect a trademark with certain qualification and reputation to be entitled as a well known trademark, and it supposed to be also including in the situation that the trademark is not registered in particular country. The existence of the trademark in other countries and its reputation worldwide supposed to be an undeniable proof of an existence of an international trademark.

\section{Conclusion}

In conclusion, the commercial and supreme court have used the criteria of well-known trademarks as stipulated in Trademark Law, Permenkumham of Trademark Registration, and WIPO Joint Recommendation in identifying a well-known trademark. However, the implementation is still inconsistent and the criteria is so widely open for interpretation. Firstly, it is inconsistent because even though Indonesia admits the well-known trademark, there is still case that prior to the first to file principle like in 'STARCO' case that even though Starco Europe has been established before, still, the judges considered the 'STACO' by Solihin Jaya as a lawful party to use the trademark because they were the one who register the trademark firsly in Indonesia. On the other hand, 'Mcqueen' case show that the judges won 'Alexander Mcqueen' by considering that even though the similar trademark namely 'McQueen' has been firstly registered in Indonesia, but the 'Alexander McQueen' has exist before 'McQueen', so that the 'McQueen' has been considered against the law and made in a bad faith). Those cases show that the idea of well-known trademark doctrine which is to protect marks with high reputation in the other member states even though the trademarks are not registered in the particular member states still not enforced completely. It is understandable because Indonesian legal system uses the first to file principle in trademark law which actually incoherence with the wellknown trademark doctrine. Thus, Authors suggest revision for the coming law to put the first to file principle for the national trademark only, and for the

18 Andry Setiawan, Dewi Sulistianingsih, and Ivan Bhakti Yudistira, "Non-Traditional Trademarkss in Indonesia: Protection under The Laws and Regulations (An Intellectual Property Law)", Journal of Indonesian Legal Studies 2, no. 2 (2017): 123-130, 124, DOI: 10.15294/jils.v2i02.19443. 
well-known trademark, the assessment must be based on the well-known trademark criteria. Secondly, the emptiness of the detailed criteria of a wellknown trademark has made the judgement on it becomes widely opened for interpretation. In case of 'NWB', judges considered it as a well-known trademark because it has been registered in 22 countries, in 'Mcqueen', it is admitted as a well-known trademark because it has been registered in 9 countries. Meanwhile, in SAMHWA case, judges did not make assessment because they could not verify the registration of the trademark in the claimed 5 countries. So, what if it was confirmed? Or what if a trademark only registered in two or one country? This criteria of the 'number of registration or application' must be governed more precisely. In the cases of 'GS', it is shown that the judges considered the 'level of legal enforcement' to admit the trademark as a well-known. This one also need to be limited in more detail to give a clear boundary. Thus, for those two concrete issue, Authors suggest that regarding the minimum number of registration or application, a trademark shall be considered as a well-known trademark if the mark has been registered at least in the country of origin of trademark plus at least in 6 out of top 10 countries with the biggest population in the world. Based on worldmeters.info, in 2020, 10 biggest countries in the world based on population are China, India, United States, Indonesia, Pakistan, Brazil, Nigeria, Bangladesh, Rusia, and Mexico. The registration and or application in at least 6 of out of the 10 countries would mean that the trademark is exist among big number of people and even dominance number of population, so that they are known or at least by the fiction of law known by most of the people in the world. Meanwhile, for the level of legal enforcement, there must be at least two cases which sentence a trademark as a well-known trademark. It is important to have at least two cases to prove that the first enforcement has been confirmed by the another court to support the position of the trademark position as a well-known trademark. Thus, to accommodate the two suggestions, the international convention must be renewed by adding more precise criteria as been suggested and those change must also be followed by the amendment of the national regulation.

\section{References}

Bairagi, Ashutosh. "Trademark and the Problem of Its Infringement in The Case of Deceptive Similarity", in International Journal of Scientific Research 5, no. 3, 2016: 315-316.

Bania, Doug. "Can Trademark Infringement Be a Victimless Crime? The Stone v. Omnia Case". International Journal of Law and Public Administration 1, no. 2, 2018: 41-46, DOI: 10.11114/ijlpa.v1i2.3879.

Bird, Robert C., Steckel, Joel H. "The Role of Consumer Surveys in Trademark Infringement: Empirical Evidence from the Federal Courts". J. BUS. L. 14, no. 4, 2012: 1013-1053. 
Cela, Miresi. "The Importance of Trademarks and A Review of Empirical Studies". 4, no. 3, 2015: 125-134, DOI: 10.14207/ejsd.2015.v4n3p125.

Chirani, Ebrahim., Teleghani, Mohammad., Moghadam, Nasim Esmailie. "Brand Performanca and Brand Equity", Interdisciplinary Journal of Contemporary Research Business 3, no. 9, 2012: 1033-1036.

Choudhary, Vivek Kumar. "Protection of Well Known Trademarks and Weakening of Honest Concurrent User Defense", Journal of Intellectual Property Rights 15, no. 4, 2010: 300-310.

Greenhalgh, Christine and Elizabeth Webster. "Have Trademarks Become Deceptive?", The WIPO Journal 6, no. 2, 2013: 1-8.

Grinvald, Leah Chan. "The Tale of Two Theories of Well-Known Marks". Vanderbilt Journal of Entertainment and Technology Law 13, no. 1 (2010): 18-26.

Irawan., Bustani, "Analisis Pembatalan Merek Superman yang Memiliki Persamaan Pada Keseluruhnya Menurut UU Nomor 20 Tahun 2016 (Studi Putusan Nomor 1105K/PDT.SUS-HKI/2018)", Jurnal Hukum Adigama 3, no. 1, 2020): 841-865, DOI: 10.24912/adigama.v3i1.8929.

Jeon, Joo-Eon. "The Impact of Brand Concept on Brand Equity", Asia Pacific Journal of Innovation and Entrepreneurship 11, no. 2, 2017: 233-245, DOI: 10.1108/APJIE-08-2017-030.

Khan, Tahsan Rahman. "Family Businesses That Produce Counterfeits: What is Stopping Them From Creating Their Own Brand?", Procedia Economics and Finance 4, 2012: 304-311, DOI: 10.1016/s22125671(12)00345-0.

Law number 20 Year 2016 Concern on Trademarks and Geographical Indications.

Luo, Jing 'Brad'., Ghosh, Subha. "Protection and Enforcement of WellKnown Mark Rights in China: History, Theory, and Future", Northwestern Journal of Technology and Intellectual Property 7, no. 2, 2009: 119-161, DOI: 10.2139/ssrn.1326398.

Malliaris, P. Stylianos. "Protecting Famous Trademarks: Comparative Analysis of US and EU Diverging Approaches- The Battle Between Legislatures and The Judiciary Who Is The Ultimate Judge?", The Chicago-Kent Journal of Intellectual Property 9, no. 1, 2010: 45-59.

Nemlioglu, Ilayda Nemlioglu., Mallick, Sushanta K. "Do InnovationIntensive Firms Mitigate Their Valuation Uncertainty During Bad Times?". Journal of Economic Behaviour and Organization 177, 2020: 913-940, DOI: 10.1016/j.jebo.2020.06.004.

Paris Convention

Setiawan, Andry, Dewi Sulistianingsih, and Ivan Bhakti Yudistira. "NonTraditional Trademarkss in Indonesia: Protection under The Laws and 
Regulations (An Intellectual Property Law)", Journal of Indonesian Legal Studies 2, no. 2, 2017: 123-130, DOI: 10.15294/jils.v2i02.19443.

Susliana, Irina and Polina Mineeva. "Use of Digital Technologies for Optimizing The Handling of Trademarkss Application", Procedia Computer Science 169, 2020: 435-439, DOI: 10.1016/j.procs.2020.02.242.

The Ministry of Law and Human Rights Regulation Number 67 Year 2016 Concern on Trademarks Registration.

Trade Related Intellectual Property Rights (TRIPs) Agreement

Yen, Alfred C. "Intent and Trademarks Infringement", Arizona Law Review 57, no. 3 (2015): 715-745.

\section{Grants}

This research is funded by the Directorate General of Higher Education of Republic of Indonesia (Dikti) through a Novice Lecturer Research Grant Scheme (2020 Conduction). 


\section{.}

